Original Research Paper

\title{
Pendampingan Kegiatan Belajar Nonformal pada Siswa-Siswi di Desa Sedau Narmada Lombok Barat
}

\author{
Aidal Fitri ${ }^{1}$, Alfira Rosalia², Kurnia Anggriani' ${ }^{2}$, Sania Zamira ${ }^{3}$, Kusmiyati $^{4 *}$ \\ ${ }^{1}$ Program Studi Pendidikan Guru Sekolah Dasar, FKIP Universitas Mataram \\ ${ }^{2}$ Program Studi Pendidikan Bahasa Inggris, FKIP Universitas Mataram \\ ${ }^{3}$ Program Studi Pendidikan Bahasa dan Sastra Indonesia, FKIP Universitas Mataram \\ ${ }^{4}$ Program Studi Pendidikan Biologi, FKIP Universitas Mataram
}

https://doi.org/10.29303/jpmpi.v3i2.1418

Sitasi: Fitri, A., Rosalia, A., Anggriani, K., Zamira, S \& Kusmiyati. (2022). Pendampingan Kegiatan Belajar Nonformal pada Siswa-Siswi di Desa Sedau Narmada Lombok Barat. Jurnal Pengabdian Magister Pendidikan IPA, 5(1)

\section{Article history}

Received: 11 Januari 2022

Revised: 01 Februari 2022

Accepted: 07 Februari 2022

*Corresponding Author:

Kusmiyati, Fakultas

Keguruan dan Ilmu

Pendidikan, Universitas

Mataram, Mataram, Indonesia;

Email:

kusmiyati.fkip@unram.ac.ic

\begin{abstract}
Tujuan pendampingan belajar non-formal di posko KKN yang terletak di Dusun Paok Gading Desa Sedau adalah untuk membantu siswa dalam melakukan kegiatan belajar. Kegiatan ini dilakukan dari bulan November-Desember 2021. Pelaksanaan kegiatan ini melalui beberapa tahapan yaitu 1). Memotivasi siswa siswi; 2). Menyampaikan gambaran umum materi yang akan diajarkan; 3). Ceramah; 4). Tanya jawab; 5). Permainan berupa kuis; 6). Pemberian hadiah (reward). Kegiatan pendampingan belajar pada masyarakat mendapat sambutan positif dari pihak orang tua, dengan memberikan ijin putra putrinya mengikuti kegiatan, terlihat banyak siswa yang hadir setiap ada jadwal belajar di posko KKN. Selama kegiatan, siswa yang hadir mengikuti dari awal hingga akhir. Pihak sekolah juga menyambut positip karena kegiatan pendampingan belajar siswa ini sesuai dengan kebutuhan mereka dan memotivasi siswa agar lebih bersemangat dalam belajar. Kesimpulan dari kegiatan ini adalah: 1). Antusias siswa-siswi sangat tinggi dalam mengikuti proses pembelajara, terlihat dari banyaknya siswa-siswi yang hadir dalam setiap proses pembelajaran; 2).Semangat belajar siswa-siswi sangat tinggi, terlihat dari siswa-siswi yang sangat aktif saat proses pembelajaran
\end{abstract}

Keywords: Pendampingan, Belajar, Non Formal

\section{Pendahuluan}

Pendidikan adalah usaha sadar untuk menyiapkan peserta didik melalui kegiatan bimbingan, pengajaran dan atau latihan bagi peranannya di masa yang akan datang. Pelaksanaan kegiatan pendidikan sebagian besar telah dilakukan dalam sekolah formal, tetapi tidak selamanya pendidikan di sekolah formal berjalan dengan lancar dan memberikan hasil sesuai yang diharapkan. Beberapa anak mengalami hambatan dan kesulitan dalam belajar, seperti hambatan berprestasi dan kurangnya motivasi untuk belajar. Hal ini, dilihat dari sebagian anak menunjukkan hasil prestasi yang kurang maksimal, semangat dan motivasi belajar masih kurang serta kecenderungan waktu yang digunakan untuk bermain lebih dominan dari pada untuk belajar.

Kondisi yang terjadi pada masyarakat umumnya adalah menginginkan setiap anak yang telah menempuh pendidikan di sekolah dapat lulus dengan memperoleh nilai ujian yang maksimal, untuk melanjutkan ke jenjang sekolah berikutnya. Berbagai macam usaha ditempuh oleh orang tua siswa untuk bisa menambah pemahaman belajar anak yang menempuh pendidikan di sekolah. Pendidikan secara formal saja tidak cukup untuk meningkatkan pemahaman belajar siswa, sehingga banyak yang menempuh pendidikan non-formal pada bimbingan belajar diluar jam belajar sekolah (Ari, et al., 2015). Fenomena tersebut menggambarkan bahwa pendidikan formal tidaklah 
dalam menghadapi berbagai macam ujian seperti ujian sekolah.

Hal tersebut tentu diperlukan upaya nyata dari semua kalangan masyarakat untuk mengatasi problematika dalam bidang pendidikan yang implementasinya dapat dilakukan di sekolah, dirumah, maupun di lingkungan. Menurut Agustina (2019), berbagai upaya untuk mengatasi problematika pendidikan ini dapat di lakukan melalui kegiatan pendampingan belajar yang merupakan bagian dari bentuk pengabdian pada masyarakat. Bentuk pendampingan belajar ini dilakukan oleh Mahasiswa KKN PLP Universitas Mataram dari bulan November-Desember 2021.

Kegiatan pendampingan belajar siswa merupakan proses pemberian bantuan bagi individu (siswa) dalam belajar diluar jam sekolah. Selain itu, membantu siswa untuk menyelesaikan tugas yang diberikan oleh gurunya di sekolah, memberikan motivasi, dan kuis pada siswa. Adanya kegiatan pendampingan belajar non formal ini diharapkan siswa dapat memperoleh pendidikan semaksimal mungkin dengan bantuan bimbingan belajar diluar pendidikan formal, dikarenakan setiap anak berhak memperoleh pembelajaran yang dapat memudahkan mereka untuk memahami dan mengerti pelajaran serta tugas-tugas yang diberikan oleh guru di sekolah.

\section{Metode Pelaksanaan}

Pendampingan siswa melalui kegiatan bimbingan belajar nonformal ini dilakukan di posko KKN PLP Universitas Mataram yang terletak di desa Sedau Kecamatan Narmada, Kabupaten Lombok Barat. Kegiatan ini diikuti oleh partisipan siswasiswi SD di desa Sedau, yang terdiri dari SDN 1 Sedau, SDN 2 Sedau dan SDN 3 Sedau, dengan jumlah total siswa yang mengikuti kegiatan setiap hari sebanyak 30 siswa. Kegiatan belajar nonformal ini diikuti oleh siswa-siswi yang berada pada jenjang kelas satu sampai kelas lima, akan tetapi yang lebih dominan mengikuti kegiatan ini yaitu siswa-siswi kelas empat dan lima. Pendampingan kegiatan belajar nonformal ini didampingi oleh mahasiswa KKN PLP Universitas Mataram dengan memberikan materi pembelajaran yang digemari oleh siswa-siswi tersebut, seperti Bahasa inggris, Matematika dan Kesenian. Adapun metode yang digunakan dalam pendampingan kegiatan belajar nonformal ini yaitu dengan menggunakan metode ceramah, tanya jawab dan praktek. Metode ceramah dan tanya jawab digunakan ketika memberikan materi tambahan sesuai pokok bahasan yang dibahas Metode praktek, digunakan untuk praktek langsung pengucapan Bahasa Inggris yang benar ataumengerjakan soalsoal matematik.

Fasilitas yang digunakan untuk menunjang pelaksanaan kegiatan ini adalah posko KKN PLP Universitas Mataram, papan tulis sederhana, alat tulis menulis, buku pelajaran siswa dan beberapa makanan ringan (snacke) dan permen sebagai hadiah (reward) untuk siswa-siswi yang aktif slama proses kegiatan pembelajaran berlangsung. Pelaksanaan kegiatan ini dilakukan selama bulan November dan Desember 2021. Waktu pelaksaannya berlangsung pada siang hari pukul 11.00 -selesai.

Pelaksanaan kegiatan bimbingan belajar menggunakan beberapa tahapan yaitu 1). Memotivasi siswa siswi agar lebih semangat belajar 2). Menyampaiakan gambaran umum materi yang akan diajarkan 3). Ceramah atau penjelasan materi 4). Tanya jawab 5). Permainan berupa kuis 6). Pemberian hadiah (reward) berupa pujian atau penghargaan secara lisan dan makanan.

\section{Hasil dan Pembahasan}

Kegiatan pendampingan bimbingan belajar nonformal siswa-siswi yang merupakan salah satu program kerja dari kegiatan kuliah kerja nyata (KKN) PLP mahasiswa Universitas Mataram di desa Sedau, Kecamatan Narmada, Kabupaten Lombok Barat. Kegiatan pengabdian kepada masyarakat ini memberikan banyak manfaat, wawasan dan pengetahuan kepada anak-anak di desa Sedau, terutama dalam meningkatkan motivasi serta prestasi belajar siswa. Pelaksanaan kegiatan bimbingan belajar dengan menerapkan beberapa tahapan yaitu

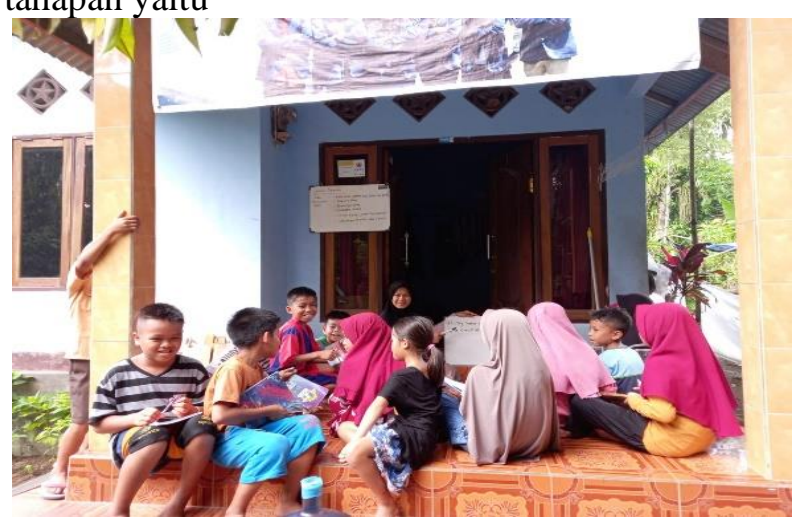

Gambar 1.1. Kegiatan Bimbingan Belajar di Posko KKN PLP

Tahapan pertama yaitu memotivasi siswa-siswi, sebelum memulai pelajaran, pendamping belajar 
memberikan motivasi kepada siswa-siswi berupa kata-kata penyemangat dan motivasi kehidupan seperti cerita-cerita inspriratif yang dapat mendorong minat siswa-siswi agar lebih antusias dalam belajar

Tahapan kedua yaitu menyampaikan gambaran umum materi pelajaran, dalam hal ini pembimbing menjelaskan materi secara umum kepada siswasiswi, seperti dalam pelajaran Bahasa inggris, pembimbing terlebih dahulu memberikan kosakata yang mudah di hafal. Pada pelajaran matematika, pembimbing mengulas kembali pelajaran yang sudah dipelajari sebelumya, sehingga, ketika dalam proses belajar siswa-siswi lebih mudah memahami pembelajaran

Tahapan ketiga yaitu ceramah atau penjelasan materi yang berisi penjelasan materi bidang studi, yang disampaikan oleh mahasiswa KKN PLP. Pemberian materi sesuai dengan kebutuhan siswa siswi di Desa Sedau, materi pelajaran matematika diajarkan sesuai dengan jenjang kelas yaitu kelas empat dan lima secara bergantian karena pada kelas tersebut telah mendekati ujian akhir semester dan materi yang diajarkan disesuaikan dengan tugas sekolah, misalnya tentng pecahan, contoh soal: Tentukan bentuk sederhana dari 12/16 Jawab : $12 / 16=(12: 4) /(16: 4)=3 / 4)$ (Nayla, 2017), Bidang Geometri, contohnya, Sebuah lingkaran berjari-jari $10 \mathrm{~cm}$, berapakah keliling lingkaran tersebut?

Jawab diketahui :

$$
\begin{aligned}
& \mathrm{r}=10 \mathrm{~cm} \\
& \pi=3,14 \\
& \text { maka }: \\
& \mathrm{K}=2 \times \pi \times \mathrm{r} \\
& \mathrm{K}=2 \times 3,14 \times 10
\end{aligned}
$$

$\mathrm{K}=62 \mathrm{~cm}$ (Adecahyani, p. 2011), sedangkan materi Bahasa Inggris disetarakan untuk semua jenjang kelas yaitu materi dasar yang dibutuhkan dalam kegiatan sehari-hari yaitu, Introduction (Hello my friends, my full name is Aida Putri, you can call me Aida, Iam ten years old), Greeting (good morning, good afternoon, how are you?) dan Vocabulary (Family: Father, Mother, Sister and Brother) (Zuhroh, 2020), siswa-siswi diminta untuk mempraktikan secara langsung materi yang sudah diberikan,

Tahapan keempat yaitu tanya jawab, dilaksanakan untuk mengetahui sejauh mana pemahaman siswa terhadap penjelasan yang telah disampaikan, siswa diberikan kesempatan untuk bertanya dan menjawab pertanyaan dari pembimbing, tugas pembimbing adalah meluruskan jawaban dari siswa dan menjawab apabila ada pertanyaan yang belum bisa terjawab. Bagi siswa yang bertanya dan menjawab diberikan poin khusus berupa pujian untuk memotivasi keaktifan siswa.

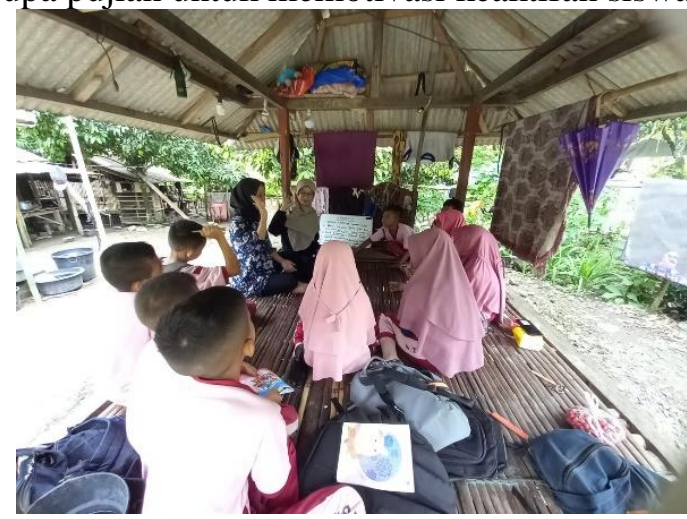

Gambar 2. Kegiatan Bimbingan Belajar di Berugak Posko KKN PLP

Tahapan kelima yaitu permainan berupa kuis yang bertujuan mengasah kemampuan siswa dengan memberikan soal-soal yang menantang. Tahapan kuis ini berupa petunjuk untuk melengkapi kalimat yang kosong dengan beberapa kata dan mengerjaka beberapa soal yang disediakan oleh pembimbing, tahapan ini juga bertujuan untuk mengukur pemahaman siswa-siswi dalam menerima materi pelajaran.

Tahapan terakhir yaitu pemberian hadiah (reward) berupa pujian secara lisan dan barang, tahapan ini bertujuan untuk meningkatkan keaktifan dan sikap antusias siswa-siswi mengikuti kegiatan belajar, penghargaan yang berupa pujian diberikan kepada siswa-siswi yang aktif selama kegiatan belajar berlangsung dan juga memberikan jajan sebagai penghargaan karena sudah mengikuti proses belajar sampai akhir.

Kegiatan pendampingan belajar pada masyarakat mendapat sambutan positif dari pihak orang tua, dengan memberikan ijin putra putrinya mengikuti kegiatan ini. Hal ini terlihat dari banyaknya siswa yang hadir setiap ada jadwal belajar di posko KKN. Selama kegiatan, siswa yang hadir mengikuti dari awal hingga akhir. Pihak sekolah juga menyambut positip karena kegiatan pendampingan belajar siswa ini sesuai dengan kebutuhan mereka dan memotivasi siswa agar lebih bersemangat dalam belajar. 


\section{Kesimpulan}

Pelaksanaan kegiatan pendampingan belajar nonformal siswa-siswi Desa Sedau telah terlaksana dengan baik, dilihat dari:

1. Antuasias siswa-siswi sangat tinggi dalam mengikuti proses pembelajara, terlihat dari banyaknya siswa-siswi yang hadir dalam setiap proses pembelajaran.

2. Semangat belajar siswa-siswi sangat tinggi, terlihat dari siswa-siswi yang sangat aktif saat proses pembelajaran.

\section{Ucapan Terima Kasih}

Terimakasih kepada Universitas Mataram dan LPPM Universitas Mataram yang telah memfasilitasi kegiatan ini dan juga kepada semua pihak yang telah mendukung pelaksanaan kegiatan ini, khususnya seluruh peserta KKN desa Sedau Kecamatan Narmada Kabupaten Lombok Barat Nopember 2021-Januari 2022.

\section{Daftar Pustaka}

Adecahyani. (n.d.). matematika geometri. elib.unikom.

Agustina, E., Rohma, Kuspiyah. (2019). Pendampingan Bimbingan Belajar Bahasa Inggris dan Bakti Sosial di Yayasan Pendidikan dan Sosial RoudlotutThullab. Jurnal Indonesia Mengabdi, 1 (1) 1-5.

Ari, Ardhi, W. (2015). Analisis Kepuasaan Siswa Terhadap Kegiatan Pembelajaran Biologi Pada Sekolah Formal Dan Lembaga Bimbingan Belajar Non-Formal diKota Madiun. Jurnal Penelitian LPPM IKIP PGRI Madiun. 3 (1) 1-5.

Nayla, I. (2017) Materi Pecahan Matematika Kelas 4 SD. SRIBD.

Zuhroh, F. (2020). Conversation for Kids. Listen English. 